\title{
Management of Breast Cancer during Pregnancy: Are We Compliant with Current Guidelines?
}

\author{
Victoria Shlensky, MD ${ }^{1}$ Sigrun Hallmeyer, MD $\quad$ Lourdes Juarez, MD ${ }^{1} \quad$ Barbara V. Parilla, MD ${ }^{1}$ \\ ${ }^{1}$ Division of Maternal-Fetal Medicine, Department of Obstetrics and \\ Gynecology, Advocate Lutheran General Hospital, Park Ridge, Illinois \\ 2 Division of Hematology and Oncology, Center for Advanced Care, \\ Advocate Lutheran General Hospital, Park Ridge, Illinois \\ Address for correspondence Barbara V. Parilla, MD, Division of \\ Maternal-Fetal Medicine, Department of Obstetrics and Gynecology, \\ Center for Advanced Care, Advocate Lutheran General Hospital, \\ 1875 W Dempster St., Suite 325, Park Ridge, IL 60068 \\ Am J Perinatol Rep 2017;7:e39-e43. \\ (e-mail: Barbara.Parilla@advocatehealth.com).
}

\begin{abstract}
Introduction The purpose of this study was to evaluate the management of patients with breast cancer in pregnancy treated at the Advocate Health Care, to determine whether these patients were treated according to guidelines for pregnant patients, which aim to maximize both fetal and maternal outcomes.

Methods A retrospective chart review was performed at the Advocate Lutheran General Hospital, Christ Medical Center, and Illinois Masonic Medical Center from 2002 to 2012 on patients diagnosed with breast cancer during pregnancy using ICD-9 (International Classification of Diseases - 9th version) codes.

Results Eleven patients between 12 and 37 weeks' gestation matched the search criteria. One patient terminated the pregnancy. Patients in our study were treated appropriately according to guidelines with the following exceptions. Trastuzumab was used in one patient during pregnancy which likely caused the oligohydramnios resulting in an induction of labor at 33 weeks. Three patients were delivered preterm

Keywords

- breast cancer

- pregnancy

- chemotherapy

- sentinel node biopsy between 34 and 36 weeks without an obstetric indication. Two patients underwent sentinel node biopsy.

Conclusion The diagnosis of breast cancer in pregnancy is an infrequent but devastating diagnosis that is likely to increase. Although sentinel lymph node biopsy is not generally recommended in pregnancy, this may be an outdated guideline as using a low-dose lymphoscintigraphic technique appears to be safe in pregnancy.
\end{abstract}

Breast cancer is the most common cancer diagnosed in pregnancy and postpartum, and occurs in approximately 1 in 3,000 pregnant women. The average patient is between 32 and 38 years of age and because many women choose to delay childbearing, it is likely that the incidence of breast cancer during pregnancy will increase.

The purpose of this study was to evaluate the management of patients with breast cancer in pregnancy treated at the Advocate Health Care, to determine whether these patients were treated according to guidelines for nonpregnant patients, with some modifications to protect the fetus. These modifications include delaying chemotherapy until after the first trimester, avoiding trastuzumab and endocrine therapy during pregnancy, postponing radiation until after delivery, performing an axillary dissection instead of a sentinel lymph node biopsy (SNB), and holding chemotherapy 3 to 4 weeks prior to delivery. In addition, delivery prior to 36 weeks is not recommended in the received

October 18, 2016 accepted after revision January 3, 2017
DOI http://dx.doi.org/ 10.1055/s-0037-1599133. ISSN 2157-6998.
Copyright $\odot 2017$ by Thieme Medical Publishers, Inc., 333 Seventh Avenue, New York, NY 10001, USA. Tel: +1(212) 584-4662.

\section{License terms}

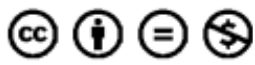


absence of an obstetric indication. These guidelines aim to maximize both fetal and maternal outcomes.

\section{Methods}

A retrospective chart review was performed at the Advocate Lutheran General Hospital, Advocate Christ Medical Center, and Advocate Illinois Masonic Medical Center from January 1, 2002, to December 31, 2013. The chart review focused on patients diagnosed with breast cancer during pregnancy. These charts were extracted using IDC9 and CPT codes corresponding to breast cancer (174.9) and pregnancy (64890, 64891, and 64892). In addition, charts were found by using the Advocate cancer registry for all women diagnosed with breast cancer. These charts were then reviewed to determine if their cancer was diagnosed during pregnancy. Patients were included if they were diagnosed with breast cancer while pregnant. Exclusion criteria included women diagnosed with breast cancer in the postpartum period and patients diagnosed with benign breast disease. Data collected included gestational age at diagnosis, gestational age at delivery, mode of delivery, stage at initial diagnosis, imaging and/or procedure used for diagnosis, treatment, pregnancy and postpartum complications, tumor receptor status, and Breast Cancer Susceptibility Gene (BRCA) status. If delivery information was available, birth weight, Apgar score, and neonatal complications were recorded.

\section{Results}

Eleven patients between 12 and 37 weeks' gestation matched the search criteria. The details of the individual

Table 1 Individual patient characteristics and treatment

\begin{tabular}{|c|c|c|c|c|c|c|c|c|c|}
\hline Pt & $\begin{array}{l}\text { GA at } \\
\text { diagnosis }\end{array}$ & $\begin{array}{l}\text { Procedure used } \\
\text { for diagnosis }\end{array}$ & Stage & Receptor $_{\text {status }}$ & $\begin{array}{l}\text { Treatment during } \\
\text { pregnancy }\end{array}$ & $\begin{array}{l}\text { GA at } \\
\text { delivery }\end{array}$ & $\begin{array}{l}\text { Mode of } \\
\text { delivery }\end{array}$ & Complications & $\begin{array}{l}\text { Treatment after } \\
\text { delivery }\end{array}$ \\
\hline 1 & 12 & $\begin{array}{l}\text { Mammogram } \\
\text { US-guided biopsy }\end{array}$ & $2 \mathrm{~B}$ & $\begin{array}{l}\text { ER neg } \\
\text { PR neg } \\
\text { Her2/Neu } \\
\text { nonamp }\end{array}$ & Termination & 14 & TAB & None & $\begin{array}{l}\text { Lumpectomy } \\
\text { Axillary dissection } \\
\text { Bilateral modified } \\
\text { mastectomy } \\
\text { Radiation }\end{array}$ \\
\hline 2 & 33 & $\begin{array}{l}\text { Mammogram } \\
\text { US-guided biopsy }\end{array}$ & $2 \mathrm{~A}$ & $\begin{array}{l}\text { Her } 2 / \mathrm{Neu} \\
\text { amp }\end{array}$ & None & 37 & $\begin{array}{l}\text { Cesarean } \\
\text { section }\end{array}$ & None & $\begin{array}{l}\text { Lumpectomy } \\
\text { Axillary dissection } \\
\text { Bilateral simple } \\
\text { mastectomy } \\
\text { Trastuzumab }\end{array}$ \\
\hline 3 & 34 & $\begin{array}{l}\text { Mammogram } \\
\text { US-guided biopsy }\end{array}$ & Unknown & Unknown & & 35 & Vaginal & None & Lumpectomy \\
\hline 4 & 26 & $\begin{array}{l}\text { Mammogram } \\
\text { US-guided biopsy }\end{array}$ & $2 \mathrm{~B}$ & $\begin{array}{l}\text { ER pos } \\
\text { PR pos } \\
\text { Her2/Neu } \\
\text { amp }\end{array}$ & $\begin{array}{l}\text { Lumpectomy } \\
\text { Chemotherapy } \\
\text { (Cytoxan, methotrexate, } \\
\text { 5-fluorouracil) }\end{array}$ & $\begin{array}{l}\text { No data } \\
\text { available }\end{array}$ & $\begin{array}{l}\text { No data } \\
\text { available }\end{array}$ & $\begin{array}{l}\text { No data } \\
\text { available }\end{array}$ & Radiation \\
\hline 5 & 30 & $\begin{array}{l}\text { Mammogram } \\
\text { US-guided biopsy }\end{array}$ & $2 \mathrm{~B}$ & $\begin{array}{l}\text { ER pos } \\
\text { PR pos } \\
\text { Her2/Neu } \\
\text { amp }\end{array}$ & $\begin{array}{l}\mathrm{R} \text { modified radical } \\
\text { mastectomy }\end{array}$ & Ongoing & $\mathrm{N} / \mathrm{A}$ & & $\mathrm{N} / \mathrm{A}$ \\
\hline 6 & 15 & $\begin{array}{l}\text { Fine needle aspiration } \\
\text { Supraclavicular LN }\end{array}$ & 4 & $\begin{array}{l}\text { ER neg } \\
\text { PR neg } \\
\text { Her2/Neu } \\
\text { amp }\end{array}$ & $\begin{array}{l}\text { Chemotherapy (Cytoxan, } \\
\text { doxorubicin, Herceptin }\end{array}$ & 33 & Vaginal & & Chemotherapy \\
\hline 7 & 12 & $\begin{array}{l}\text { Mammogram } \\
\text { US-guided biopsy }\end{array}$ & 1 & $\begin{array}{l}\text { ER pos } \\
\text { PR pos } \\
\text { Her } 2 / \text { Neu } \\
\text { amp }\end{array}$ & $\begin{array}{l}\text { Mastectomy } \\
\text { Chemotherapy } \\
\text { (Adriamycin, Cytoxan) }\end{array}$ & 37 & $\begin{array}{l}\text { Cesarean } \\
\text { section }\end{array}$ & None & $\begin{array}{l}\text { Chemotherapy } \\
\text { (Taxol/trastuzumab/ } \\
\text { tamoxifen) } \\
\text { Prophylactic mastectomy }\end{array}$ \\
\hline 8 & 18 & $\begin{array}{l}\text { Mammogram } \\
\text { US-guided biopsy }\end{array}$ & 4 & Unknown & $\begin{array}{l}\text { Chemotherapy } \\
\text { (Adriamycin, Cytoxan) }\end{array}$ & 36 & $\begin{array}{l}\text { Cesarean } \\
\text { section }\end{array}$ & None & Mastectomy \\
\hline 10 & 35 & $\begin{array}{l}\text { Mammogram } \\
\text { US-guided biopsy }\end{array}$ & $2 \mathrm{~B}$ & $\begin{array}{l}\text { ER neg } \\
\text { PR neg } \\
\text { Her2/Neu } \\
\text { neg }\end{array}$ & & 39 & Vaginal & $\begin{array}{l}\text { Postpartum } \\
\text { neutropenic } \\
\text { fever }\end{array}$ & $\begin{array}{l}\text { Chemotherapy } \\
\text { (Taxotere/Adriamycin/ } \\
\text { Cytoxan) } \\
\text { Lumpectomy } \\
\text { Sentinel lymph node } \\
\text { biopsyRadiation }\end{array}$ \\
\hline 11 & 37 & $\begin{array}{l}\text { Mammogram } \\
\text { US-guided biopsy }\end{array}$ & $2 \mathrm{~A}$ & $\begin{array}{l}\text { ER pos } \\
\text { PR pos } \\
\text { Her2/Neu amp }\end{array}$ & & 38 & $\begin{array}{l}\text { Cesarean } \\
\text { section }\end{array}$ & None & Chemotherapy \\
\hline
\end{tabular}

Abbreviations: amp, amplified; ER, estrogen receptor; GA, gestational age; Her2, human epidermal growth factor receptor 2; neg, negative; pos, positive; PR, progesterone receptor; US, ultrasound. 
patients are displayed in -Table 1. The patients were 21 to 41 years old at the time of diagnosis, with a mean age at diagnosis of 32.9 years. Of the 11 patients, 7 were Caucasian, 2 were African American, 1 was Hispanic, and 1 was Asian. The gestational age at diagnosis ranged from 12 to 37 weeks, with a mean gestational age at diagnosis of 25.9 weeks. Of the 11 patients, 10 chose to continue the pregnancy after diagnosis. One terminated the pregnancy at 14 weeks' gestation. Of the 10 patients who continued the pregnancy, the gestational age at delivery ranged from 33 to 39 weeks, with a mean gestational age at delivery of 36.2 years.

Of the 11 patients, 10 were diagnosed by an ultrasoundguided biopsy after an abnormal mammogram. One patient was diagnosed by a supraclavicular lymph node biopsy. One patient had stage 1 disease (9\%), six patients had stage $2(55 \%)$, one patient had stage $3(9 \%)$, two patients had stage 4 (18\%), and one patient with unknown pathology (9\%). Of the 11 patients, histology was available in 8 . Of the eight patients, six had invasive ductal carcinoma (75\%), one had invasive lobular carcinoma (16\%), and one had inflammatory carcinoma (16\%). Three patients were ER negative/PR negative (27\%), one patient was ER negative/PR positive (9\%), five patients were ER positive/PR positive (45\%), and two patients had an unknown receptor status (18\%). Her2 status was available in nine patients. Five were Her2 amplified (55\%) and four were Her2 nonamplified.

With respect to treatment, four patients received no treatment during pregnancy, four patients underwent surgery (two mastectomies, one lumpectomy, and two SNBs), and four patients received chemotherapy during pregnancy. Of the patients who received chemotherapy during pregnancy, two had surgery prior to initiating chemotherapy. The patients who received chemotherapy during pregnancy received Adriamycin and Cytoxan (two patients), Adriamycin, Cytoxan, Taxol, and trastuzumab (one patient), and Cytoxan, methotrexate, and 5-fluorouracil (one patient).

Of the patients who continued the pregnancy, nine patients delivered between 33 and 39 weeks.

One patient delivered at a non-Advocate hospital and her delivery information was not available. Of the nine patients with delivery information, there were three vaginal deliveries and six cesarean sections. The indication for delivery in eight of the nine deliveries was breast cancer. Only two pregnancy or postpartum complications were recorded. One patient had oligohydramnios at 33 weeks and was induced. She was receiving trastuzumab. Another patient was noted to have a postpartum neutropenic fever 8 weeks after delivery. There was one admission to the neonatal intensive care unit (NICU) for neonatal respiratory distress. That infant was released from the NICU 2 days later. Postpartum, seven patients underwent primary or completion surgery; seven patients received chemotherapy, and three patients received radiation therapy. One patient received chemotherapy and radiation in the postpartum period. Of the patients who received chemotherapy, two received trastuzumab.

\section{Discussion}

Breast cancer in pregnancy presents a challenging situation, since the welfare of both the mother and the fetus must be taken into account. Patients diagnosed with breast cancer while pregnant should receive the same treatment as nonpregnant patients with a few modifications to protect the fetus. However, the treatment should be approached with curative intent. Most of the patients in our study were treated appropriately according to recent guidelines. ${ }^{1}$ The first suggested guideline is that pregnant women should not undergo chemotherapy in the first trimester. Given that the mechanism of action of most chemotherapeutic agents is to target and destroy rapidly dividing cells, it is no surprise that these agents are teratogenic. Fetal malformations can be as high as 15 to $25 \%$ in fetuses exposed to chemotherapeutic agents during the first trimester compared with 2 to $3 \%$ of fetuses with no chemotherapy exposure. ${ }^{2}$ Although chemotherapy is not contraindicated in the second and third trimesters, about half of all fetuses with chemotherapeutic exposure during that time are at increased risk for intrauterine growth restriction, prematurity, and low birth weight. $^{3}$ None of our patients received chemotherapy in the first trimester. The patient with the earliest gestational age at diagnosis was 12 weeks and she chose to terminate the pregnancy. Although pregnancy termination may be considered during treatment planning, it has not been demonstrated to improve outcome.

Treatment with trastuzumab in Her2-positive tumors is not recommended during pregnancy as it can cause oligohydramnios. Her2 is strongly expressed in the fetal renal epithelium. In a study examining the effects of trastuzumab on pregnancy, ${ }^{4} 15$ fetuses were evaluated. Three had renal failure, four died, and eight had a decreased amniotic fluid volume. The surviving fetuses had spontaneous return of renal function in utero after the drug was stopped, and the severity was linked to the duration of exposure. The patient who received trastuzumab during pregnancy in our study was induced at 33 weeks for oligohydramnios, with an amniotic fluid index of $3.4 \mathrm{~cm}$. She delivered an infant who had a birth weight that was appropriate for gestational age and had a 5-minute Apgar score $>7$.

No patients in our cohort received hormonal agents such as selective estrogen receptor modulators, which can disturb the hormonal environment. Such treatment should be delayed until after birth. Tamoxifen has the potential to induce fetal harm during pregnancy and is associated with birth defects including craniofacial malformations, ambiguous genitalia, and fetal death. ${ }^{5}$

Chemotherapy should also be avoided 3 to 4 weeks before delivery to avoid transient neonatal myelosuppression and complications of sepsis and death. Reassuringly, there are no reported cases of childhood cancer arising in children exposed to chemotherapy for breast cancer in utero. 
As in the nonpregnant state, surgery is the definitive local treatment for early-stage breast cancer diagnosed in pregnancy. Either breast-conserving surgery or mastectomy is a reasonable option in the pregnant woman based on tumor characteristics and patient preferences. However, radiation therapy should be delayed until after delivery. Breast and axillary lymph node surgery during any trimester of pregnancy appears to be associated with minimal risk. Mastectomy may be preferable to breast-conserving surgery when the cancer is diagnosed early in pregnancy, systemic therapy is not warranted, and there would be a significant delay to radiation therapy. None of our patients received radiation therapy during pregnancy.

Although SNB using ${ }^{99 m}$ technetium appears to be safe in pregnancy, it has generally been accepted that a complete axillary dissection is safer during pregnancy, given that there is no exposure to the fetus. Gropper et $\mathrm{al}^{6}$ recently performed a study looking at the neonatal outcome of fetuses exposed to ${ }^{99} \mathrm{Tc}$ in utero secondary to a SNB. Twenty-five fetuses were identified who were exposed and only one had a neonatal complication, a cleft palate, which was thought to have been secondary to other maternal factors such as smoking and methadone use. SNB was successful in all patients, with at least one sentinel node retrieved, and with no maternal complications. Calculated or modeled fetal radiation exposure from SNB ranges from $1.14 \mu \mathrm{Gy}$ to $4.3 \mathrm{mGy}{ }^{7-9}$ well below the threshold of concern for fetal harm, and in the realm of background radiation absorbed on an average day in the United States. Lymphatic mapping with blue dye (isosulfan blue and methylene blue) is not recommended in pregnancy due to the concern for maternal anaphylaxis, which is also of concern in the nonpregnant state, and also the possibility for teratogenicity. ${ }^{10}$ However, patients with clinically positive axillary lymph nodes or with inflammatory breast cancer are most likely to derive benefit from axillary lymph node dissection.

Three patients were delivered preterm between 34 and 36 weeks without an obstetric indication. In all three patients, the indication for delivery was breast cancer. The patients were moved toward delivery to facilitate the prompt administration of chemotherapy. Despite an eagerness on behalf of the maternal physicians to initiate chemotherapy, the timing of delivery should be 37 weeks of gestation to avoid the neonatal risks of prematurity. When deciding on timing of delivery, one must weigh the maternal risks of postponing chemotherapy against the neonatal risks of prematurity.

In the literature, most pregnancy associated breast cancers are ER negative/PR negative. ${ }^{1}$ This may be the result of receptor binding by high serum estrogen levels associated with the pregnancy. Enzyme immunocytochemical receptor assays, however, are more sensitive than competitive binding assays. A study that used binding methods indicated similar receptor positivity between pregnant and nonpregnant women with breast cancer. The study concluded that increased estrogen levels during pregnancy could result in a higher incidence of receptor positivity detected with immunohistochemistry than is detected by radiolabeled ligand binding, which is because of competitive inhibition by high levels of endogenous estrogen. In our study, most of the patients who had reported receptor status were ER positive/PR positive (55\%). Seventy-five percent of the patients evaluated had invasive ductal carcinoma, which is the most common type of breast cancer outside of pregnancy. In addition, $55 \%$ of our patients were Her2 amplified.

Breast cancer diagnosed during pregnancy was thought to be more aggressive, ${ }^{11}$ but recent analyses suggest no significant differences in disease-free or overall survival in patients with breast cancer diagnosed and treated during pregnancy compared with nonpregnant comparison groups, when controlled for stage. ${ }^{12,13}$ The natural tenderness and engorgement of the breasts of pregnant and lactating women may hinder detection of discrete masses and early diagnoses of breast cancer. Therefore, delays in diagnoses are common, with an average reported delay of 5 to 15 months from the onset of symptoms. Because of this delay, cancers are typically detected at a later stage than in a nonpregnant,

age-matched population. The National Cancer Institute recommends pregnant and lactating women should practice self-examination and undergo a breast examination as part of the routine prenatal examination by a doctor.

In conclusion, the diagnosis of breast cancer in pregnancy is an infrequent but devastating diagnosis that is likely to increase. The conflict between giving life and questioning it cannot be overstated. ${ }^{14}$ Continued research in this area including a breast cancer in pregnancy registry ${ }^{15}$ with long-term outcomes is greatly needed to provide the best care possible for these patients and their families.

\section{Conflict of Interest}

The authors have no conflict of interest to report.

\section{Note}

This study was presented at the Annual Meeting of the Central Association of Obstetricians and Gynecologists, October 16-19, 2013, Napa, CA.

\section{Acknowledgment}

This is in memory of Dr. Victoria Shlensky who herself was diagnosed with breast cancer in pregnancy.

\section{References}

1 National Comprehensive Cancer Network. Guidelines breast cancer in pregnancy. Version 3. Available at: www.NCCN.org. Accessed 2013

2 Amant F, Deckers S, Van Calsteren K, et al. Breast cancer in pregnancy: recommendations of an international consensus meeting. Eur J Cancer 2010;46(18):3158-3168

3 Loibl S, Han SN, von Minckwitz G, et al. Treatment of breast cancer during pregnancy: an observational study. Lancet Oncol 2012; 13(09):887-896 
4 Azim HA Jr, Azim H, Peccatori FA. Treatment of cancer during pregnancy with monoclonal antibodies: a real challenge. Expert Rev Clin Immunol 2010;6(06):821-826

5 Isaacs RJ, Hunter W, Clark K. Tamoxifen as systemic treatment of advanced breast cancer during pregnancy-case report and literature review. Gynecol Oncol 2001;80(03):405-408

6 Gropper AB, Calvillo KZ, Dominici L, et al. Sentinel lymph node biopsy in pregnant women with breast cancer. Ann Surg Oncol 2014;21(08):2506-2511

7 Spanheimer PM, Graham MM, Sugg SL, Scott-Conner CE, Weigel RJ. Measurement of uterine radiation exposure from lymphoscintigraphy indicates safety of sentinel lymph node biopsy during pregnancy. Ann Surg Oncol 2009;16(05): 1143-1147

8 Pandit-Taskar N, Dauer LT, Montgomery L, St Germain J, Zanzonico PB, Divgi CR. Organ and fetal absorbed dose estimates from 99mTc-sulfur colloid lymphoscintigraphy and sentinel node localization in breast cancer patients. J Nucl Med 2006;47(07): 1202-1208
9 Keleher A, Wendt R III, Delpassand E, Stachowiak AM, Kuerer HM. The safety of lymphatic mapping in pregnant breast cancer patients using Tc-99m sulfur colloid. Breast J 2004;10(06):492-495

10 Gentilini O, Cremonesi M, Toesca A, et al. Sentinel lymph node biopsy in pregnant patients with breast cancer. Eur J Nucl Med Mol Imaging 2010;37(01):78-83

11 Rovera F, Chiappa C, Coglitore A, et al. Management of breast cancer during pregnancy. Int J Surg 2013;11(Suppl 1):S64-S68

12 Guidroz JA, Scott-Conner CE, Weigel RJ. Management of pregnant women with breast cancer. J Surg Oncol 2011;103(04):337-340

13 Keleher AJ, Theriault RL, Gwyn KM, et al. Multidisciplinary management of breast cancer concurrent with pregnancy. J Am Coll Surg 2002;194(01):54-64

14 Theriault RL, Litton JK. Pregnancy during or after breast cancer diagnosis: what do we know and what do we need to know? J Clin Oncol 2013;31(20):2521-2522

15 Cardonick E, Dougherty R, Grana G, Gilmandyar D, Ghaffar S, Usmani A. Breast cancer during pregnancy: maternal and fetal outcomes. Cancer J 2010;16(01):76-82 